Hal $10-20$

\title{
PENINGKATAN KEMAMPUAN KOMUNIKASI MATEMATIKA SISWA MELALUI MODEL PEMBELAJARAN RECIPROCAL TEACHING DI KELAS XI SMA NEGERI 1 SILANGKITANG
}

\author{
Eka Yunita ${ }^{1}$, Suriyani ${ }^{2}$, Rahma Muti'ah ${ }^{3}$ \\ ${ }^{1}$ Mahasiswa Program Studi Pendidikan Matematika STKIP Labuhanbatu \\ ${ }^{2}$ Dosen Program Studi Pendidikan Matematika STKIP Labuhanbatu \\ ${ }^{3}$ Dosen Program Studi Pendidikan Matematika STKIP Labuhanbatu \\ STKIP Labuhanbatu,JIn. SM. Raja No. 126A, KM, 3.5 Aek Tapa, Rantauprapat \\ Email: ekayunita122@gmail.com
}

Diterima (April 2018) dan disetujui (Mei 2018)

\begin{abstract}
ABSTRAK
Penelitian ini bertujuan untuk mengetahui apakah terdapat peningkatan kemampuan komunikasi matematika siswa memalui model pemelajaran Reciprocal Teaching di kelas XI SMA Negeri 1 Silangkitang Tahun Pembelajaran 2017/2018. Jenis penelitian ini adalah Quasi Eksperimen dengan populasi seluruh siswa kelas XI SMA Negeri 1 Silangkitang yang terdiri dari 5 kelas. Sampel penelitian di ambil 2 kelas yang ditentukan dengan teknik Random Sampling, yaitu kelas XI-IPS-2 dengan menggunakan model pembelajaran Reciprocal Teaching dan kelas XI-IPS-1 dengan menggunakan model pembelajaran konvensional. Instrument yang digunakan dalam penelitian ini adalah tes kemampuan komunikasi matematika siswa dalam bentuk essay. Data rata-rata pre-test kelas eksperimen dan kontrol sebesar 32,47 dan 32.57 . Setelah diberikan perlakuan pada masing-masing kelas diperoleh data rata-rata post-test pada kelas Eksperimen sebesar 60,47 dan pada kelas kontrol sebesar 54,10. Pada hasil pengujian $N$-Gain nilai rata-rata kelas eksperimen sebesar 28 dan pada kelas kontrol sebesar 21,53 dengan selisih rata-rata $N$ Gain kelas eksperimen dan kelas kontrol sebesar 6,47. Pada hasil pengujian hipotesis nilai ratarata $N$-Gain diperoleh pada taraf signifikan $\alpha=0,05$ dan $\mathrm{dk}=58$ nilai signifikan $0.008<0,005$. Dengan demikian berarti Ha diterima yang berarti terdapat peningkatan kemampuan komunikasi matematika siswa melalui model pembelajaran Reciprocal Teaching Di Kelas XI SMA Negeri 1 Silangkitang Tahun Pembelajaran 2017/2018.
\end{abstract}

Kata Kunci: Model Pembelajaran Reciprocal Teaching, Model Pembelajaran Konvensional, Kemampuan Komunikasi Matematika 


\section{PENDAHULUAN}

Pendidikan merupakan sarana yang digunakan pemerintah untuk meningkatkan sumber daya manusia yang mampu mengembangkan potensi yang dimilikinya. Sistem pendidikan Nasional enantiasa harus dikembangkan sesuai dengan kebutuhan dan perkembangan yang terjadi baik di tingkat local, nasional, maupun global. Selain itu pendidikan merupakan kebutuhan individu dari sejak dilahirkan dan berlangsung seumur hidup. Manusia akan sulit berkembang tanpa adanya pendidikan. Pendidikan harus diarahkan untuk membentuk manusia yang cerdas, berkualitas, berbudi pekerti luhur dan bermoral. Dengan demikian mutu pendidikan di Indonesia harus ditingkatkan. Berkaitan dengan hal tersebut, salah satu upaya langsung guna membentuk sebuah pendidikan yang berkualitas adalah melalui pembelajaran matematika.

Matematika juga berfungsi untuk melayani ilmu pengetahuan artinya selain tumbuh dan berkembang untuk dirinya sendiri sebagai suatu ilmu, matematika juga melayani kebutuhan ilmu pengetahuan dalam pengembangan dan operasionalnya. Sampai saat ini, matematika merupakan mata pelajaran wajib yang harus diberikan kepada siswa pendidikan dasar hingga menengah. Hal tersebut dikarenakan pada hakikatnya, matematika merupakan sumber dari ilmu-ilmu lain yang sangat bermanfaat bagi pendidikan siswa secara keseluruhan, baik bagi pengembangan kemampuan untuk memahami, menyampaikan dan pembentukan sikap untuk menghadapi masalah.

Pembelajaran matematika di sekolah dari jenjang pendidikan dasar hingga kelas XII memerlukan standar pembelajaran yang berfungsi untuk menghasilkan siswa yang memiliki kemampuan berfikir, kemampuan penalaran matematis, kemampuan komunikasi yang memiliki pengetahuan serta keterampilan dasar yang bermanfaat. Standar pembelajaran tersebut meliputi standar isi dan standar proses. Standar isi adalah standar pembelajaran matematika yang memuat konsep - konsep materi yang harus dipelajari oleh siswa. Sedangkan standar proses adalah kemampuan-kemampuan yang harus dimiliki siswa untuk mencapai standar isi. Standar proses meliputi: pemecahan masalah (problem solving), penalaran (reasoning), komunikasi (communication), penelusuran pola atau hubungan (connections), dan representasi (representatiation). $\begin{array}{rrr}\text { Salah } & \text { satu dari } & \text { standar proses } \\ \text { pembelajaran } & \text { adalah } & \text { komunikasi }\end{array}$ (communication). Komunikasi dalam hal ini adalah tidak sekedar komunikasi secara lisan atau verbal tetapi juga komunikasi secara tertulis tetapi siswa mampu membaca model matematika dan kemampuan untuk menyatakan ide-ide matematika baik secara lisan maupun tertulis. Komunikasi matematika bagian esensial dari matematika dan pendidikan matematika. Komunikasi merupakan cara berbagi gagasan dan klarifikasi pemahaman. Komunikasi dalam matematika merupakan kemampuan mendasar yang harus dimiliki siswa dan guru selama prose belajar dan mengajar, dan mengevaluasi matematika. Melalui komunikasi siswa memiliki kemampuan untuk mengaplikasikan dan mengekspresikan pemahaman tentang konsep dan proses matematika yang mereka pelajari.

Salah satu kompetensi yang harus dimiliki siswa adalah menggunakan bahasa untuk memahami, mengembangkan, dan mengkomunikasikan gagasan dan informasi, serta untuk berinteraksi dengan orang lain. Pada kompetensi umum bahan kajian matematika disebutkan bahwa dengan belajar matematika siswa diharapkan memiliki kemampuan mengkomunikasikan gagasan dengan simbol, tabel, grafik untuk memperjelas keadaan atau masalah.Karena kemampuan komunikasi matematika penting untuk dimiliki siswa, maka guru harus memberikan permasalahan-permasalahan yang dapat melatih kemampuan komunikasi dengan memperhatikan karakteristik model pembelajaran yang digunakan.

Berkaitan dengan hal tersebut, setelah peneliti melakukan observasi proses pembelajaran matematika yang dilaksanakan di SMA Negeri 1 Silangkitang pada tanggal 10 April 2017 ditemukan permasalahan antara lain sebagai berikut : 1). Siswa kurang mampu mengungkapkan dan mengkomunikasikan ide dan gagasan matematika ke dalam bentuk simbol dan gambar, 2). Siswa bergantung pada guru sehingga siswa bersiffat pasif pada saat pembelajaran matematika berlangsung, 3). Siswa kurang mampu menuliskan sistematika jawaban yang benar pada saat diberikan soal oleh guru. Masalah-masalah tersebut disebabkan karena guru masih menggunakan model pembelajaran konvensional. Masalah lain juga dikarenakan kurangnya minat siswa dalam mempelajari matematika. Siswa 
cenderung menganggap matematika merupakan ilmu yang sulit. Untuk mengatasi masalah tersebut maka perlu digunakan pembelajaran yang tepat sehingga dapat meningkatkan kemampuan komunikasi matematika siswa. Oleh karena itu, guru harus terus berusaha menyusun dan menerapkan berbagai model pembelajaran yang bervariasi agar siswa lebih tertarik dalam pembelajaran matematika Peningkatan kemampuan komunikasi matematika siswa dapat dilakukan dengan mengadakan perubahan-perubahan dalam pembelajaran. Dalam hal ini, perlu dirancang suatu pembelajaran yang membiasakan siswa untuk menyampaikan pemikirannya baik dengan guru, teman maupun yang orang lain. Salah satu cara yang dapat dilakukan untuk meningkatkan kemampuan komunikasi matematika siswa adalah dengan menerapkan model pembelajaran yang tepat. Model pembelajaran yang sebaiknya diterapkan adalah model pembelajaran yang memberikan kesempatan kepada siswa untuk mengkonstruksi pengetahuannya sendiri sehingga siswa lebih mudah untuk memahami konsep-konsep yang diajarkan dan mengkomunikasikan ide-idenya dalam bentuk lisan maupun tulisan.

Salah satu alternatif untuk mendukung hal tersebut adalah dengan menerapkan model Reciprocal Teaching. . Model pembelajaran Reciprocal Teaching adalah model pembelajaran berupa kegiatan mengajarkan materi kepada teman. Pada model pembelajaran ini siswa berperan sebagai "guru" untuk menyampaikan materi kepada teman-temannya. Sementara itu, guru lebih berperan sebagai model yang menjadi fasilitator dan pembimbing yang melakukan scaffolding. Scaffolding adalah bimbingan yang diberikan olehh orang yang lebih tahu kepada orang yang kurang tahu atau belum tahu. Melalui model pembelajaran Reciprocal Teaching siswa diajarkan empat strategi pemahaman pengaturan diri spesifik yaitu perangkuman, pengajuan pertanyaan, pengklarifikasian dan prediksi. Berdasarkan uraian permasalahan di atas, peneliti tertarik untuk mengadakan suatu penelitian yang berjudul "Peningkatan Kemampuan Komunikasi Matematika siswa Melalui Model Reciprocal Teaching Di Kelas XI SMA Negeri 1 Silangkitang".

\section{TINJAUAN PUSTAKA \\ Kemampuan Komunikasi Matematika}

Komunikasi adalah suatu proses dimana individu menyampaikan sesuatu secara verbal kepada orang lain dengan tujuan merubah tingkah laku pendengarnya (Bansu, 2016:11). Menurut Rachmayani (2014:14) menyatakan bahwa komunikasi merupakan cara berbagi gagasan dan klarifikasi pemahaman. Adapun indikator-indikator kemampuan komunikasi matematika adalah sebagai berikut :

Tabel 1 Indikator Tes Kemampuan Komunikasi Matematika

\begin{tabular}{|l|l|}
\hline \multicolumn{1}{|c|}{ Indikator Kemampuan Komunikasi } & Indikator yang akan dicapai \\
\hline $\begin{array}{l}\text { Kemampuan siswa dalam membaca dan } \\
\text { menafsirkan data ke dalam ide matematika }\end{array}$ & $\begin{array}{l}\text { Siswa mampu membaca dan } \\
\text { menafsirkan data kedalam ide } \\
\text { matematika }\end{array}$ \\
\hline $\begin{array}{l}\text { Kemampuan siswa dalam membaca dan } \\
\text { menafsirkan data ke dalam bentuk model } \\
\text { matematika }\end{array}$ & $\begin{array}{l}\text { Siswa mampu membaca an } \\
\text { menafsirkan data ke dalam model } \\
\text { matematika }\end{array}$ \\
\hline $\begin{array}{l}\text { Kemampuan siswa menyajikan pernyataan } \\
\text { matematika }\end{array}$ & $\begin{array}{l}\text { Siswa mampu menyajikan } \\
\text { pernyataan matematika. }\end{array}$ \\
\hline Kemampuan memvisualisasikan masalah. & $\begin{array}{l}\text { Siswa mampu memvisualisasikan } \\
\text { masalah. }\end{array}$ \\
\hline $\begin{array}{l}\text { Kemampuan menentukan konsep dari } \\
\text { suatu persoalan. }\end{array}$ & $\begin{array}{l}\text { Siswa mampu menentuka konsep } \\
\text { dari suatu persoalan. }\end{array}$ \\
\hline
\end{tabular}

\section{Model Pembelajaran Reciprocal Teaching}

Reciprocal Teaching adalah model pembelajaran berupa kegiatan pengajaran materi kepada teman. Pada model ini siswa berperan sebagai "guru" untuk menyampakan materi kepada teman-temannya. Sementara itu, guru lebih berperan sebagai model yang menjadi fasilitator dan pembimbing yang 
Hal $10-20$

melakukan scaffolding. Menurut Aris Shoimin (2014:153) kegiatan-kegiatan dalam model pembelajaran Reciprocal Teaching meliputi 4 strategi:

1. Menyusun pertanyaan (question generating)

2. Membuat ringkasan (clarifying)

Tabel 2 Langkah-langkah Model Pembelajaran Reciprocal Teaching
3. Membuat prediksi (predicting)

4. Mengklasifikasi atau mencatat hal-hal yang kurang jelas dari bacaan.

Adapun langkah-langkah model pembelajaran Reciprocal Teaching adalah sebagai

berikut:

\begin{tabular}{|c|l|ll|}
\hline Fase & \multicolumn{1}{|c|}{ Langkah } & \multicolumn{1}{c|}{ Kegiatan guru } \\
\hline 1 & Membentuk Kelompok & $\begin{array}{l}\text { Guru membentuk kelompok siswa yang didasarkan pada } \\
\text { kemampuan yang siswa. } \\
\text { Setelah kelompok terbentuk guru membagikan materi kepada } \\
\text { siswa. }\end{array}$ \\
\hline 2 & $\begin{array}{l}\text { Membuat Pertanyaan } \\
\text { (Question Generating) }\end{array}$ & $\begin{array}{l}\text { Guru meminta siswa membuat pertanyaan tentan materi yang } \\
\text { dibahas kemudian menyampaikannya di depan kelas. }\end{array}$ \\
\hline 3 & $\begin{array}{l}\text { Menyajikan Hasil Kerja } \\
\text { Kelompok }\end{array}$ & $\begin{array}{l}\text { Guru meminta salah satu kelompok untuk menjelaskan hasil } \\
\text { diskusi mereka di depan kelas, sedangkan kelompok yang } \\
\text { lain dapat menanggapi atau bertanya. }\end{array}$ \\
\hline 4 & $\begin{array}{l}\text { Mengklarifikasi } \\
\text { Permasalahan } \\
\text { Clarifying) }\end{array}$ & $-\begin{array}{l}\text { Guru memberikan kesempatan siswa untuk bertanya tentang } \\
\text { materi yang dianggap sulit kepada guru. } \\
\text { Guru berusaha menjawab dengan memberikan pertanyaan } \\
\text { pancingan kepada siswa. } \\
\text { Guru mengadakan tanya jawab terkait materi yang dipelajari } \\
\text { untuk mengetahui sejauh mana tingkat pemahaman siswa }\end{array}$ \\
\hline 5 & $\begin{array}{l}\text { Memberikan } \\
\text { Latihan (Predicting) }\end{array}$ & $\begin{array}{l}\text { Guru memberikan soal latihan kepada siswa untuk dikerjakan } \\
\text { secara individu. }\end{array}$ \\
\hline 6 & $\begin{array}{l}\text { Menyimpulkan Materi } \\
\text { (Summarizing) }\end{array}$ & $-\begin{array}{l}\text { Guru meminta siswa untuk menyimpulkan materi yang telah } \\
\text { dibahas. }\end{array}$ \\
\hline
\end{tabular}

\section{METODOLOGI PENELITIAN}

Penelitian ini adalah penelitian dengan metode quasi-eksperiment. Penelitian komparatif adalah suatu penelitian yang bersifat membandingkan. Tujuan dari penelitian quasieksperiment adalah untuk mengetahui pengaruh atau hubungan sebab-akibat dengan cara membandingkan hasil kelompok eksperimen yaitu kelompok yang memperoleh perlakuan pembelajaran matematika yang menggunakan model pembelajaran Reciprocal Teaching dengan kelompok kontrol yaitu kelompok yang memperoleh pembelajaran matematika yang menggunakan model pembelajaran konvensional. Lokasi penelitian berada di SMA Negeri I Silangkitang, Kabupaten Labuhanbatu Selatan. Adapun waktu penelitian dilaksanakan pada semester I Tahun Pelajaran 2017/2018 pada bulan juli selama 3 kali pertemuan dengan setiap kali pertemuan 2x45 menit. Desain perlakuan dapat dilihat pada Tabel 3.

Tabel 3 Pretest Posttest Control Open-ended Design

\begin{tabular}{|c|c|c|c|}
\hline Kelas & $\begin{array}{c}\text { Tes Awal } \\
\text { (Pretest) }\end{array}$ & Perlakuan & $\begin{array}{c}\text { Tes Akhir } \\
\text { (Posttest) }\end{array}$ \\
\hline Eksperimen & $\mathrm{Y}_{1}$ & $\begin{array}{c}\text { Model } \\
\text { Pembelaja } \\
\text { ran } \\
\text { Reciprocal }\end{array}$ & $\mathrm{Y}_{2}$ \\
\hline
\end{tabular}


Hal $10-20$

\begin{tabular}{|c|c|c|c|}
\hline & & Teaching & \\
\hline Kontrol & $\mathrm{Y}_{1}$ & $\begin{array}{c}\text { Model } \\
\text { Konvensio } \\
\text { nal }\end{array}$ & $\mathrm{Y}_{2}$ \\
\hline
\end{tabular}

\section{Keterangan :}

$Y_{1}$ : tes kemampuan awal kemampuan penalaran matematika sebelum diberikan model pembelajaran

$\mathrm{Y}_{2}$ : tes kemampuan akhir kemampuan penalaran matematika setelah diberikan model pembelajaran

Sampel pada penelitian ini adalah siswa kelas XI IPS-2 yang berjumlah 30 siswa sebagai kelas eksperimen dan siswa kelas XI IPS-1 yang berjumlah 30 siswa sebagai kelas kontrol dengan jumlah seluruh sampel adalah 60 siswa. Instrumen yang digunakan dalam penelitian ini adalah tes kemampuan komunikasi matematika sebanyak 5 soal yang digunakan untuk pre-test dan post-test. Analisis pada penelitian ini dibantu menggunakan software SPSS 17, untuk pengujian hipotesis menggunakan uji $\mathrm{t}$ yaitu independent sample $t$ test, namun sebelum dilakukan uji t terlebih dahulu dilakukan uji normalitas dengan menggunakan uji Kolmogorov-Smirnov dan homogenitas dengan menggunakan uji Analysis Of Varians (ANOVA).

\section{HASIL DAN PEMBAHASAN PENELITIAN}

\section{Deskripsi Data Pre-Test Kelas Eksperimen dan Kelas Kontrol}

Dari hasil penelitian yang dilakukan pada bulan Juli 2017 di SMA Negeri 1 Silangkitang didapatkan data pretest pada kelas eksperimen dan kelas kontrol sebagai berikut:

Tabel 4 Hasil Nilai pre-test Komunikasi Matematika Siswa Kelas Eksperimen dan Kelas Kontrol

\begin{tabular}{|c|c|c|c|c|}
\hline \multirow{2}{*}{ No. } & \multirow{2}{*}{ Kategori } & \multirow{2}{*}{ Interval Nilai } & \multicolumn{2}{c|}{ Frekuensi } \\
\cline { 4 - 5 } & & & Eksperimen & Kontrol \\
\hline 1 & Tinggi & $54-80$ & - & - \\
\hline 2 & Sedang & $28-53$ & 28 & 27 \\
\hline 3 & Rendah & $1-27$ & 2 & 3 \\
\hline \multicolumn{3}{|c|}{ Jumlah } & 30 siswa & 30 siswa \\
\hline
\end{tabular}

Berdasarkan tabel diatas terlihat bahwa kemampuan komunikasi matematika siswa kelas eksperimen 28 berkategori sedang dan 2 orang siswa berkategori rendah. Pada kelas kontrol siswa berkategori sedang 27 dan 3 orang siswa berkategori rendah

Tabel 5 Rekapitulasi Hasil Pretest

\begin{tabular}{|c|c|c|c|c|c|c|}
\hline \multirow[b]{2}{*}{ No } & \multirow[b]{2}{*}{ Kelas } & \multirow[b]{2}{*}{$\mathbf{N}$} & \multicolumn{4}{|c|}{ Nilai } \\
\hline & & & $\begin{array}{l}\text { Skor } \\
\text { Ideal }\end{array}$ & $\begin{array}{c}\text { Skor } \\
\text { minimum }\end{array}$ & Skor maksimum & Rata-Rata \\
\hline 1 & Eksperimen & 30 & 80 & 25 & 38 & 32,47 \\
\hline 2 & Kontrol & 30 & 80 & 25 & 41 & 32,57 \\
\hline
\end{tabular}

Hasil rata-rata pretest yang didapatkan pada kelas eksperimen maupun kelas kontrol 
Hal $10-20$

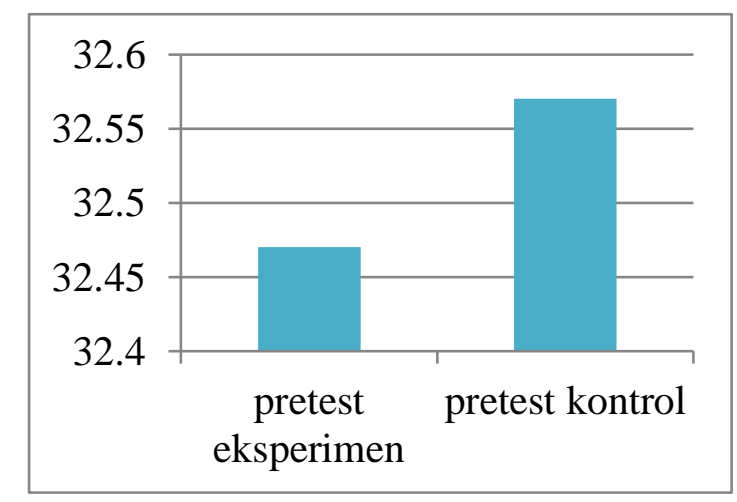

Gambar 1. Diagram Batang Rata-Rata Hasil Pretest Kelas Eksperimen dan Kelas Kontrol

\footnotetext{
Berdasarkan diagram batang di atas dapat dilihat rata-rata Pretest kelas eksperimen adalah 32,47 dan kelas kontrol adalah 32,57 .
}

\section{Deskripsi Data Post-Test Kelas Eksperimen dan Kelas Kontrol}

Dari hasil penelitian yang dilakukan pada bulan Juli 2017 di SMA Negeri 1 Silangkitang didapatkan data posttest pada kelas eksperimen dan kelas kontrol sebagai berikut :

Tabel 6. Hasil Nilai Post-Test Komunikasi Matematika Siswa Kelas Eksperimen dan Kelas Kontrol

\begin{tabular}{|c|c|c|c|c|}
\hline \multirow[b]{2}{*}{ No. } & \multirow[b]{2}{*}{ Kategori } & \multirow[b]{2}{*}{$\begin{array}{c}\text { Interval } \\
\text { Nilai }\end{array}$} & \multicolumn{2}{|c|}{ Frekuensi } \\
\hline & & & $\begin{array}{c}\text { Eksperi } \\
\text { men }\end{array}$ & Kontrol \\
\hline 1 & Tinggi & $54-80$ & 26 & 17 \\
\hline 2 & Sedang & $28-53$ & 4 & 13 \\
\hline 3 & Rendah & $1-27$ & - & - \\
\hline & & & siswa & 30 siswa \\
\hline
\end{tabular}
siswa dan 17 orang siswa yang memiliki nilai

Berdasarkan tabel diatas terlihat bahwa kemampuam penalaran matematika siswa kelas XI SMA Negeri 1 Silangkitang pada kelas eksperimen 4 orang siswa kategori sedang dan 26 orang siswa kategori tinggi. Pada kelas eksperimen nilai post-test siswa yang mimiliki nilai berkategori sedang sebanyak 13 orang

Tabel 7 Rekapitulasi Hasil Posttest

\begin{tabular}{|c|c|c|c|c|c|c|}
\hline \multirow{2}{*}{ No } & \multirow{2}{*}{ Kelas } & \multirow{2}{*}{$\mathbf{N}$} & \multicolumn{4}{|c|}{ Nilai } \\
\cline { 4 - 7 } & & $\begin{array}{c}\text { Skor } \\
\text { Ideal }\end{array}$ & $\begin{array}{c}\text { Skor } \\
\text { minimu } \\
\text { m }\end{array}$ & $\begin{array}{c}\text { Skor } \\
\text { maksim } \\
\text { um }\end{array}$ & $\begin{array}{c}\text { Rata- } \\
\text { Rata }\end{array}$ \\
\hline 1 & Eksperimen & 30 & 80 & 38 & 75 & 60,47 \\
\hline
\end{tabular}


Hal $10-20$

\begin{tabular}{|l|l|l|l|l|l|l|}
\hline 2 & Kontrol & 30 & 80 & 38 & 65 & 54,10 \\
dapat dilihat pada diagram batang sebagai \\
berikut :
\end{tabular}

Hasil rata-rata posttest yang didapatkan

pada kelas eksperimen maupun kelas kontrol

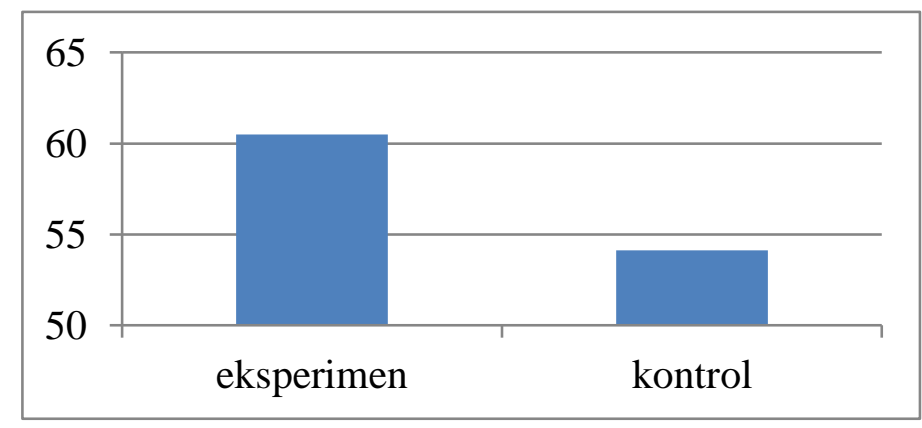

\section{Gambar 2. Diagram Batang Hasil Rata-Rata Nilai Posttest Kelas Eksperimen dan Kelas Kontrol}

Berdasarkan diagram batang di atas dilihat rata-rata Posttest kelas eksperimen adalah 60,47 dan kelas kontrol adalah 54,10 .

Tabel 8 Rekapitulasi Hasil N-Gain

\begin{tabular}{|c|l|c|c|c|c|}
\hline \multirow{2}{*}{ No } & \multirow{2}{*}{ Kelas } & \multirow{N}{*}{$\mathbf{N}$} & \multicolumn{4}{|c|}{$\begin{array}{c}\text { Skor } \\
\text { minimum }\end{array}$} & $\begin{array}{c}\text { Skor } \\
\text { maksimum }\end{array}$ & $\begin{array}{c}\text { Rata- } \\
\text { Rata }\end{array}$ \\
\hline 1 & Eksperimen & 30 & 5 & 44 & 28 \\
\hline 2 & Kontrol & 30 & 6 & 39 & 21,53 \\
\hline
\end{tabular}

Berdasarkan data yang diperoleh pada tabel 8 di atas dapat dilihat nilai minimum, nilai maksimum dan rata-rata $N$-Gain kelas eksperimen lebih tinggi dibandingkan dengan kelas kontrol. Dimana nilai minimum pada kelas eksperimen adalah 5 sedangkan pada kelas kontrol adalah 6 . Nilai maksimum pada kelas eksperimen adalah 44 sedangkan pada kelas kontrol adalah 39. Nilai rata-rata $\mathrm{N}$-Gain pada kelas eksperimen adalah 28 sedangkan pada kelas kontrol adalah 21,53. Maka dapat disimpulkan bahwa $N$-Gain pada kelas eksperimen lebih tinggi dari pada $N$-Gain kelas kontrol. Dengan selisih rata-rata $N$-Gain kelas eksperimen dan kontrol adalah 6,47.

Berdasarkan hasil pengujian normalitas data $N$-Gain untuk kelas eksperimen dengan menggunakan SPSS diperoleh nilai sig $>$ taraf signifikan $(\alpha=0,05)$ yaitu $0,090>0,05$ dan untuk kelas kontrol diperoleh nilai sig $>$ taraf signifikan $(\alpha=0,05)$ yaitu $0,089>0,05$, yang artinya bahwa data $N$ Gain kelas kontrol dan eksperimen berdistribusi normal.

Berdasarkan hasil pengujian homogenitas data $N$-Gain dengan menggunakan SPSS diperoleh nilai $s i g>$ taraf taraf signifikan $(\alpha=0,05)$ yaitu $0,180>0,05$ yang artinya data $\mathrm{N}$-Gain kelas kontrol dan eksperimen homogen atau memiliki varians yang sama.

Berdasarkan hasil pengujian untuk uji-t diperoleh nilai Sig (2-tailed) < taraf taraf signifikan $(\alpha=0,05)$ yaitu $0,008<0,05$. Keputusan yang diperoleh adalah $\mathrm{H}_{0}$ ditolak, maka data miliki nilai signikan yang berbeda. Ini artinya siswa pada kelas eksperimen yang diajarkan melalui model pembelajaran Reciprocal Teaching memiliki kemampuan komunikasi matematika yang berbeda dengan siswa kelas kontrol diajarkan melalui model pembelajaran konvensional. Peningkatan kemampuan penalaran ini terlihat dari nilai rata-rata $\mathrm{N}$-Gain kelas eksperimen lebih tinggi dibandingkan dengan kelas kontrol. Nilai ratarata $N$-Gain pada kelas eksperimen adalah 28 sedangkan pada kelas kontrol adalah 21,53. Maka dapat disimpulkan bahwa $N$-Gain pada kelas eksperimen lebih tinggi dari pada $N$-Gain kelas kontrol. Dengan selisih rata-rata $N$-Gain kelas eksperimen dan kontrol adalah 6,47.

\section{Proses Jawaban Siswa KelasEksperimen} dan Kelas Kontrol 
Hal $10-20$

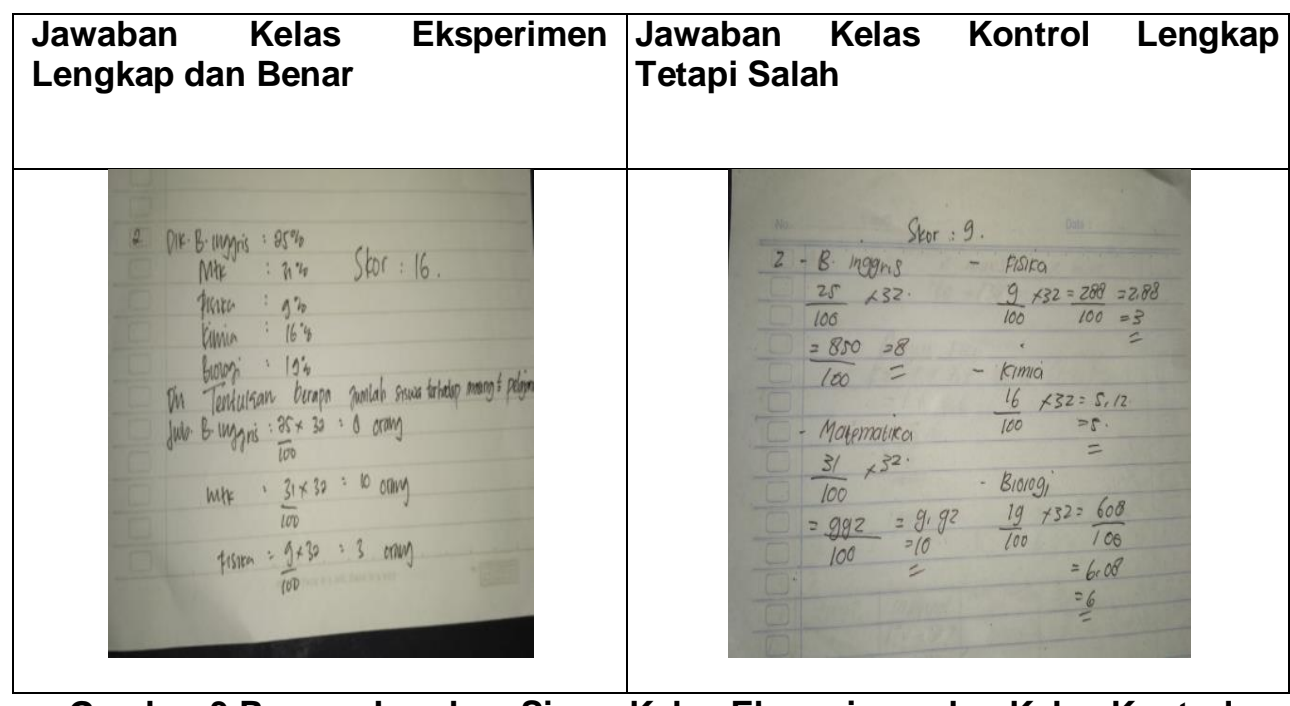

Gambar 3 Proses Jawaban Siswa Kelas Eksperimen dan Kelas Kontrol

Berdasarkan proses jawaban siswa di atas, ini merupakan hasil proses jawaban siswa pada kelas eksperimen yang pengajarannya dengan menggunakan model pembelajaran Reciprocal Teaching dan kelas kontrol yang diajarkan dengan menggunakan model pembelajaran konvensional. Pada jawaban kelas eksperimen siswa mampu membaca dan menafsirkan data ke dalam ide matematika hal ini terlihat pada gambar proses jawaban siswa kelas eksperimen diatas siswa mampu menuliskan hal-hal yang diketahui dan di tanyakan dengan benar dan lengkap sedangkan pada gambar proses jawaban siswa kelas kontrol diatas dapat terlihat bahwa siswa tidak menuliskan hal-hal yang diketahui dan di tanyakan. Kemudian pada kelas eksperimen siswa mampu menyajikan pernyataan matematika hal ini terlihat pada strategi yang dibuat sudah mengarah pada jawaban yang benar. Sedangkan pada kelas kontrol kemampuan siswa dalam meyajikan pernyataan matematika sudah benar tetapi jawaban siswa salah hal ini dapat terlihat dari gambar proses jawaban siswa pada kelas kontrol di atas. Pada kelas eksperimen siswa mampu memvisualisasikan masalah hal ini terlihat dari gambar proses jawaban siswa kelas eksprimen di atas hasil dan prosedur siswa dalam mengerjakan soal yang diberikan benar sedangkan pada kelas kontrol sebagian hasil salah, tetapi hanya salah perhitung. Pada kelas eksperimen siswa mampu menentukan konsep dari suatu persoalan hal ini terlihat dari gambar proses jawaban siswa kelas eksperimen siswa mampu menjawab soal dengan dan lengkap sesuai dengan yang ditanyakan sehingga sedangkan pada gambar proses jawaban siswa kelas kontrol siswa menjawab soal tetapi hasilnya salah. Dari uraian di atas telihat bahwa siswa kelas eksperimen yang diajarkan dengan menggunakan model pembelajaran Reciprocal Teaching lebih mampu menjawab soal sesuai dengan indikator kemampuan komunikasi matematika siswa.

\begin{tabular}{|c|c|}
\hline $\begin{array}{c}\text { Jawaban Kelas Eksperimen } \\
\text { Lengkap Tetapi Salah }\end{array}$ & $\begin{array}{c}\text { Jawaban Kelas Kontrol Tidak } \\
\text { Lengkap Tetapi Salah }\end{array}$ \\
\hline & \\
\hline & \\
\hline
\end{tabular}




\section{Gambar 4 Proses Jawaban Siswa Kelas Eksperimen dan Kelas Kontrol}

Berdasarkan proses jawaban siswa di atas, ini merupakan hasil proses jawaban siswa pada kelas eksperimen yang pengajarannya dengan menggunakan model pembelajaran Reciprocal Teaching dan kelas kontrol yang diajarkan dengan menggunakan model pembelajaran konvensional. Pada jawaban kelas eksperimen siswa mampu membaca dan menafsirkan data ke dalam ide matematika hal ini terlihat pada gambar proses jawaban siswa kelas eksperimen diatas siswa mampu menuliskan hal-hal yang diketahui dan di tanyakan dengan benar dan lengkap sedangkan pada gambar proses jawaban siswa kelas kontrol diatas dapat terlihat bahwa siswa tidak menuliskan hal-hal yang diketahui dan di tanyakan. Kemudian pada kelas eksperimen siswa mampu menyajikan pernyataan matematika hal ini terlihat pada strategi yang dibuat sudah mengarah pada jawaban yang benar. Sedangkan pada kelas kontrol kemampuan siswa dalam meyajikan pernyataan matematika sudah benar tetapi jawaban siswa salah hal ini dapat terlihat dari gambar proses jawaban siswa pada kelas kontrol di atas. Pada kelas eksperimen kemampuan memvisualisasikan masalah siswa sudah benar hal ini terlihat dari gambar proses jawaban siswa kelas eksperimen di atas siswa kelas eksperimen hanya sebagian hasil perhitungan salah sedangkan pada kelas kontrol siswa mampu menjawab soal yang diberikan tetapi hasil perhitungannya salah. Pada kelas eksperimen siswa mampu menentukan konsep dari suatu persoalan hal ini terlihat dari gambar proses jawaban siswa kelas eksperimen siswa mampu menjawab soal, tetapi hasil perhitungan salah sedangkan pada gambar proses jawaban siswa kelas kontrol dalam menjawab soal jawaban yang diberikan siswa salah. Dari gambar di atas telihat bahwa siswa kelas eksperimen yang diajarkan dengan menggunakan model pembelajaran Reciprocal Teaching lebih mampu menjawab soal sesuai dengan indikator kemampuan komunikasi matematika siswa.

\section{Pembahasan Penelitian}

Hasil analisis data rata-rata pretest tes kemampuan komunikasi matematika siswa kelas XI SMA Negeri 1 Silangkitang tahun pembelajaran 2017/2018 pada kelas eksperimen dan kelas kontrol adalah sebesar 32,47 dan 32,57. Kemudian pada kelas eksperimen siswa diajarkan dengan menggunakan model pembelajaran Reciprocal Teaching sehingga peningkatan rata-rata nilai posttest adalah 60,47 . Sedangkan pada kelas kontrol peningkatan rata-rata nilai posttest adalah 54,10. Hasil rata-rata $N$-Gain pada kelas eksperimen sebesar 28 sedangkan hasil rata-rata $N$-Gain pada kelas kontrol sebesar 21,53 dengan selisih nilai rata-rata $N$-Gain kelas eksperimen dan kelas kontrol sebesar 6,47 . Maka dapat disimpulkan peningkatan komunikasi matematikia siswa yang diajarkan dengan model pembelajaran Reciprocal Teaching lebih tinggi dari pada kemampuan komunikasi matematika yang diajarkan dengan menggunakan model pembelajaran konvensional.

Untuk menganalisis data pada penelitian ini menggunakan uji-t pada SPSS dengan pengambilan keputusan tolak $\mathrm{H}_{0}$ jika nilai Sig<Taraf Signifikan $(\alpha=0,05)$. Hasil uji-t dimana nilai Sig (2-tailed) untuk data $N$-Gain adalah 0,008 . Keputusan yang diperoleh adalah $\mathrm{H}_{0}$ ditolak karena $0,008<0,05$, maka data miliki nilai signikan yang berbeda. Ini artinya siswa pada kelas eksperimen yang diajarkan melalui model pembelajaran Reciprocal Teaching memiliki kemampuan komunikasi matematika yang berbeda dengan siswa kelas kontrol diajarkan melalui model pembelajaran konvensional. Dengan hasil pengujian $0,008<0,05$ yang artinya bahwa terdapat peningkatan yang signifikan kemampuan komunikasi matematika siswa kelas XI SMA Negeri 1 Silangkitang tahun pembelajaran 2017/2018 pada saat diberi perlakuan.

Hasil penelitian ini juga sejalan dengan hasil penelitian yang dilakukan oleh Rachmayani dengan hasil uji statistik terhadap skor gain yang diperoleh dari hasil pretes dan postes terhadap kemampuan komunikasi matematis siswa di dapatkan hasil rata-rata gain untuk kelas eksperimen adalah 0,67 dengan standar deviasi $(s)=0,1333$ dan ratarata gain untuk kelas kontrol adalah 0,57 dengan standar deviasi $(\mathrm{s})=0,513$. Berdasarkan hasil tersebut dapat disimpulkan bahwa kemampuan komunikasi matematis siswa yang mempergunakan pembelajaran reciprocal teaching lebih baik daripada siswa yang menggunakan pembelajaran langsung. Sedangkan untuk kemandirian belajar siswa 
yang diperoleh dari hasil uji perbedaan ratarata untuk 1 sisi sebesar 0,187 yang menyebabkan sig >0,05, berdasarkan kriteria pengujian disimpulkan tidak terdapat perbedaan kemandirian belajar siswa antara yang menggunakan pembelajaran reciprocal teaching dengan yang menggunakan pembelajaran langsung.

Dalam proses pembelajaran terdapat model serta pendekatan pembelajaran yang mempengaruhi pengembangan kemampuan komunikasi matematika siswa dalam belajar matematika di kelas.

Berdasarkan hasil proses jawaban siswa terlihat bahwa siswa kelas eksperimen yang diajarkan dengan menggunakan model pembelajaran Reciprocal Teaching dapat menjawab soal sesuai dengan indicator kemampuan komunikasi matematika siswa. Pada kelas eksperimen kemampuan siswa dalam membaca dan menafsirkan data ke dalam ide dan model matematika lebih tinggi dari pada kemampuan siswa kelas kontrol. Selain itu siswa kelas eksperimen lebih mampu menyajikan pernyataan matematika dan memvisualisasikan masalah dengan benar. Pada kelas eksperimen kemampuan siswa dalam menentukan konsep dari suatu persoalan lebih tinggi dari pada kemampuan siswa kelas kontrol. Berdasarkan hasil proses jawaban siswa yang telah dikerjakan kelas eksperimen dan kelas kontrol terlihat bahwa hasil LAS pada kelas eksperimen lebih baik dari pada hasil LAS kelas kontrol hal ini terlihat dari soal nomor 1 kelas eksperimen mendapatkan hasil skor 14 sedangkn kelas kontrol menadapatkan hasil skor 5. Pada soal nomor 2 kelas eksperimen mendapatkan hasil skor 16 sedangkan kelas kontrol mendapatkan hasil skor 9 .

\section{PENUTUP}

Terdapat peningkatan kemampuan penalaran matematika siswayang diajarkan dengan menggunakan model pembelajaran Reciprocal Teaching pada materi statistik di kelas XI SMA Negeri 1 Silangkitang. Hal ini dapat dibuktikan dari nilai rata-rata $N$-Gain pada kelas eksperimen yang diajarkan dengan model pembelajaran Recipcoral Teaching lebih tinggi dari nilai rata-rata kelas kontrol yang diajar dengan metode pembelajaran konvensional $(28>21,53)$. Demikian juga berdasarkan hasil perhitungan uji Independent $T$ Test pada nilai $N$-Gain diperoleh nilai Sig. (2-tailed) sebesar 0,008 . Nilai Sig. (2-tailed) $<0,05$ artinya hasil uji $T$ kelas eksperimen dan kelas kontrol dinyatakan terdapat perbedaan. Jadi dapat disimpulkan bahwa terdapat peningkatan kemampuan komunikasi matematika siswa yang diajarkan dengan menggunakan model pembelajaran Reciprocal Teaching.

\section{DAFTAR PUSTAKA}

Bansu, I. 2016. Komunikasi Matematik, Strategi Berfikir, dan Manajemen Belajar. Banda Aceh : PeNA.

Dwi, Rachmayani. 2014. Penerapan Pembelajaran Reciprocal Teaching Untuk Meningkatkan Kemampuan Komunikasi Matematis Dan Kemandirian Belajar Matematika Siswa. Universitas Muhammadiyah Jakarta. Jurnal Pendidikan Unsika Volume 2 Nomor 1. November 2014.

Eva, Fransiska Sijabat. (2016). Pengaruh Model Reciprocal Teaching Terhadap Kemampuan Komunikasi Matematika Siswa Kelas XI SMA Negeri 3 Lubuk Linggau Tahun Pelajaran 2015/2016. STIKIP PGRI Lubuk Linggau.

Aisyah, Juliani.(2015). Meningkatkan Kemampuan Komunikasi Matematis Siswa Menggunakan Model Pembelajaran Kooperatif Tipe Student Teams Achiviement Division (Stad). Pendidikan Matematika FKIP Universitas Lambung Mangkurat Jl. Brigjen $H$. Hasan Basry Kayutangi Banjarmasin.

Hidayah, Ansori. (2016). Meningkatkan Kemampuan Komunikasi Matematis Siswa Melalui Model Pembelajaran Contextual Teaching And Learning Kelas Viii Smp. Program Studi Pendidikan Matematika FKIP UNLAM. EDU-MAT Jurnal Pendidikan Matematika, Volume 4, Nomor 1, April 2016, hlm $32-39$.

Nova, Dwi Jayanti. (2014). Peningkatan Kreativitas Belajar Matematika Melalui Strategi Pembelajaran Reciprocal Teaching Bagi Siswa Kelas Xi Semester Gasal Smk Harapan Kartasura Tahun 2013/2014. Universitas Muhammadiyah Surakarta. 
Vol.4, No.1 Mei 2018

Hal $10-20$

Wiranataputra, S. (2007). Teori Belajar dan Pembelajara\$n. Jakarta : Universitas Terbuka Departemen Pendidikan Nasional.

Nurul, Atika Herman. (2014). Penerapan Model Reciprocal Teaching Pada Pembelajaran Matematika Siswa Kelas Viii Smpn 26 Padang. Universitas Negeri Padang. Vol. 3 No. 1 (2014) Jurnal Pendidikan Matematika : Part 2 Hal 13-17.

Aprilia, Ulfa. (2016). Pengaruh Model Reciprocal Theaching Terhadap Hasil Belajar Matematika Siswa Kelas XI IPA SMA Negeri Tugumulyo Tahun Pelajaran 2015/2016. STIKIP PGRI Lubuklinggau. 